\title{
Review
}

\section{Embryogenesis-related genes; Its expression and roles during somatic and zygotic embryogenesis in carrot and Arabidopsis}

\author{
Miho Ikeda ${ }^{1,2}$, Mikihisa Umehara ${ }^{1,3}$, Hiroshi Kamada ${ }^{1 *}$ \\ ${ }^{1}$ Graduate School of Life and Environmental Sciences, Gene Research Center, University of Tsukuba, Tsukuba, Ibaraki \\ 305-8572, Japan; ${ }^{2}$ Plant Gene Function Research Team, Gene Function Center, National Institute of Advanced \\ Industrial Sciences and Technology, Center 4, Higashi 1-1-1, Tsukuba, Ibaraki 305-8562, Japan; ${ }^{3}$ Department of \\ Biotechnology, Fukuoka Agricultural Research Center, Yoshiki 587, Chikushino, Fukuoka 818-8549, Japan \\ *E-mail: hkamada@sakura.cc.tsukuba.ac.jpＴel: +81-29-853-4674Ｆax: +81-29-853-7746
}

Received December 15, 2005; accepted January 30, 2006 (Edited by T. Kohchi)

\begin{abstract}
There are two types of embryogenesis in plants: zygotic and somatic. Recently, some new tissue culture systems of somatic embryo formation have been established in Arabidopsis thaliana. Studies that use these somatic embryo induction systems together with classical tissue culture systems of carrot somatic embryos have shown that some embryogenesis-related genes ( $L E A$ genes, SERK, AGL15, BBM, LEC1, FUS3 and ABI3) were expressed in the same manner in both zygotic and somatic embryogenesis. ABA signal transduction in the late stage of embryogenesis was also shown to be common in both types of embryos. These findings showed that somatic and zygotic embryogeneses are physiologically and molecularly similar, and that tissue culture systems for somatic embryogenesis can be practically used to study the mechanism of plant embryogenesis. The somatic embryo tissue culture systems will enable the mechanism of plant embryogenesis to be understood, thereby providing much knowledge in this field.
\end{abstract}

Key words: ABA signaling, embryonic genes, somatic embryogenesis, zygotic embryogenesis.

Embryogenesis is one of the most important steps in the life cycle of plants. The process begins with double fertilization, followed by determination of the three axes of embryos (longitudinal, lateral, and radial) and morphologic changes of the embryos (globular, heartshaped, and torpedo-shaped). Subsequently, seed storage proteins accumulate in the embryos, and finally, the embryos become desiccated and dormant. These processes are regulated by numerous factors, including phytohormones, enzymes, and other substances related to embryogenesis. Many studies have been conducted using diverse experimental techniques aiming to understand the mechanisms that control plant embryogenesis. Somatic embryogenesis tissue culture systems were found to be one of the most useful experimental tools in this field.

Since the first reports on carrot in 1958 (Reinert 1958; Steward et al. 1958), somatic embryogenesis has been reported in various plant species. During somatic embryogenesis, differentiated somatic cells (e.g., epidermal cells of the leaf, root, stem, hypocotyls and cotyledon) dedifferentiate first, and then the cells acquire the potential to form embryos in tissue culture conditions, form embryos that are morphologically similar to zygotic embryos, and develop into seedlings. The development of somatic embryos closely resembles the development of zygotic embryos both morphologically and physiologically. Therefore, somatic embryogenesis has been extensively used as an experimental system to investigate the morphological, biochemical and physiological events of embryogenesis (Zimmerman 1993). Especially in carrot, a large quantity of somatic embryos of the same developmental phase can be easily obtained using a tissue culture system, making carrot a widely used model plant for researches on somatic embryogenesis.

In recent years, molecular biological approaches have also been used to investigate embryogenesis. Several genes that are related to cell differentiation, morphogenesis, desiccation tolerance, and signal transduction are expressed during embryogenesis and function as part of the embryogenesis program. Many embryo-defective mutants have been isolated and analyzed from Arabidopsis, which serves as a model

Abbreviations: ABA, abscisic acid; ABI3, ABA INSENSITIVE 3; ABRE, ABA responsive element; AGL15, AGAMOUS-like 15; BBM, BABY BOOM; CdCl, cadmium chloride; EC, embryogenic cell; FUS3, FUSCA 3; GA, gibberellic acid; LEA proteins, late-embryogenesis abundant proteins; LEC, LEAFY COTYLEDON; SE, somatic embryo; SERK, somatic embryogenesis receptor kinase; VP1, VIVIPAROUS 1; ZE, zygotic embryo; 2,4-D, 2,4-dichlorophenoxyacetic acid.

This article can be found at http://www.jspcmb.jp/ 
plant for molecular genetics. However, the majority of the genes that caused the embryo-defective mutants were related to housekeeping phenomena (e.g., cell division, cell differentiation, phytohormone response and other indispensable survival processes), and only few embryogenesis-specific genes have been found. Thus, many aspects of the embryogenesis program remain to be elucidated.

In this review, we discuss models of somatic embryogenesis that are likely useful for the molecular biological analyses of embryogenesis, and also describe recent findings made using somatic and zygotic embryogenesis systems of carrot and Arabidopsis.

\section{Tissue culture system for somatic embryogenesis in Arabidopsis thaliana}

Arabidopsis is a widely used model plant to study diverse genetic and molecular biological phenomena including embryogenesis. However, embryogenesis is difficult to analyze using Arabidopsis, because their developing embryos are very small. Since the 1990s, Arabidopsis systems in which somatic embryos are induced have been developed to resolve this problem. In Arabidopsis, somatic embryos have been induced from immature zygotic embryos (Sangwan et al. 1992; Wu et al. 1992) and from protoplasts of leaf-derived cells (O'Neill and Mathias 1993). In this section, we describe the somatic embryogenesis of Arabidopsis from immature zygotic embryos and shoot apical meristems. These tissue culture systems are useful tools to investigate the molecular mechanisms of embryogenesis.

\section{Somatic embryo induction from immature zygotic embryos of Arabidopsis}

Sangwan et al. (1992) and Wu et al. (1992) reported systems for inducing somatic embryos from immature Arabidopsis zygotic embryos. Wu et al. (1992) showed that the somatic embryos induced from immature zygotic embryos using this system could grow into plantlets, and that the developmental phase of material zygotic embryos was vital in inducing the callus formation and the development of somatic embryos. Using a modified version of this culture system, Pillon et al. (1996) found that embryogenic cells (ECs) could be induced from primary somatic embryos obtained from immature zygotic embryos and that secondary somatic embryos were formed from the ECs. The EC maintained the embryogenic competence over one year on solid medium. However, the proliferation rate of the EC was low. Therefore, this system failed to provide somatic embryos sufficient for biochemical and molecular biological experimentation.

Ikeda-Iwai et al. (2002) modified Pillon's culture system and established a reproducible tissue culture system (Figure 1). In this newly established system, ECs were formed from the primary somatic embryos cultured in liquid culture, and secondary embryos were formed from the ECs. The liquid culture system increased both the cell proliferation rate and the quantities of yellow ECs and somatic embryos. However, the embryogenic competence of ECs was decreased within 2 months of culture in this system. These facts indicate that embryogenic competence was lost rapidly in liquid culture. The ECs with low embryogenic competence increased in transparency, and produced multiple adventitious roots instead of becoming somatic embryos under the liquid culture conditions. However, when ECs with decreased embryogenic competence were cultured on a solid medium under light, secondary green somatic embryos were formed. The green somatic embryos resembled the primary somatic embryos formed from immature zygotic embryos, and new ECs could be induced from the secondary green somatic embryos.

In this tissue culture system, high embryogenic competence can be restored repeatedly, and sufficient amounts of Arabidopsis embryonic tissues, including

Figure 1. Tissue culture systems for the induction of Arabidopsis somatic embryos. Somatic embryogenesis from immature zygotic embryos: The young green siliques of Arabidopsis thaliana (L.) Heynh. (Columbia) were collected and surface-sterilized. Immature seeds were selected from the siliques, and immature zygotic embryos were isolated. These were placed on agar-solidified B5 medium containing 4.5 $\mu \mathrm{M} 2,4-\mathrm{D}$. Somatic embryogenesis was observed after 8-21 days. The somatic embryos could grow into normal plantlets. Reproducible tissue culture system for the induction of large quantities of somatic embryos: The somatic embryos derived from immature zygotic embryos were transferred to liquid B5 medium containing 9.0 $\mu \mathrm{M}$ 2,4-D in order to induce embryogenic cell clusters (ECs) which were composed of embryogenic cells and secondary somatic embryos. ECs were subcultured every two weeks in B5 medium containing 9.0 $\mu \mathrm{M} 2,4-\mathrm{D}$. To induce morphologically differentiated somatic embryos, two-week-old cultures of ECs were washed five times with phytohormone-free liquid B5 medium and transferred to phytohormone-free liquid B5 medium. The somatic embryos developed into perfect plantlets. The ability of the ECs to transform into somatic embryos decreased during repeated subculturing in liquid B5 medium containing $9.0 \mu \mathrm{M}$ 2,4-D. The ECs were transferred onto solid B5 medium containing 4.5 $\mu \mathrm{M} 2,4-\mathrm{D}$ and cultivated under conditions of continuous white light $\left(50 \mu \mathrm{mol}\right.$ photons $\left.\mathrm{m}^{-2} \mathrm{~s}^{-1}\right)$ at $21^{\circ} \mathrm{C}$. Green somatic embryos formed after about 10 days and were transferred to liquid B5 medium containing $9.0 \mu \mathrm{M}$ 2,4-D. The green somatic embryos developed into ECs once more after 14 days of incubation. Somatic embryos were derived from these ECs by the method described above. Stress-induced somatic embryogenesis: Shoot apical-tip explants (ca. $1 \mathrm{~mm}$ length) of 5-day-old seedlings and various tissue explants, including floral-bud explants of 8- to 12-week-old plants, were placed onto agar-solidified phytohormone-free B5 medium containing $0.7 \mathrm{M}$ osmoticum (mannitol, sorbitol, or sucrose), $0.3 \mathrm{M} \mathrm{NaCl}$ or $0.6 \mathrm{mM} \mathrm{CdCl}$. The explants were cultured under the stress conditions for 0-24h, washed with liquid B5 medium, transferred onto agar-solidified B5 medium containing $4.5 \mu \mathrm{M} 2$,4-D without the stress chemical, and cultured under continuous white light $\left(40 \mu \mathrm{mol}\right.$ photons $\left.\mathrm{m}^{-2} \mathrm{~s}^{-1}\right)$ at $21^{\circ} \mathrm{C}$. After $10-20$ days of culture, the explants that formed somatic embryos were transferred onto agar-solidified phytohormone-free B5 medium and allowed to grow into mature plants. 


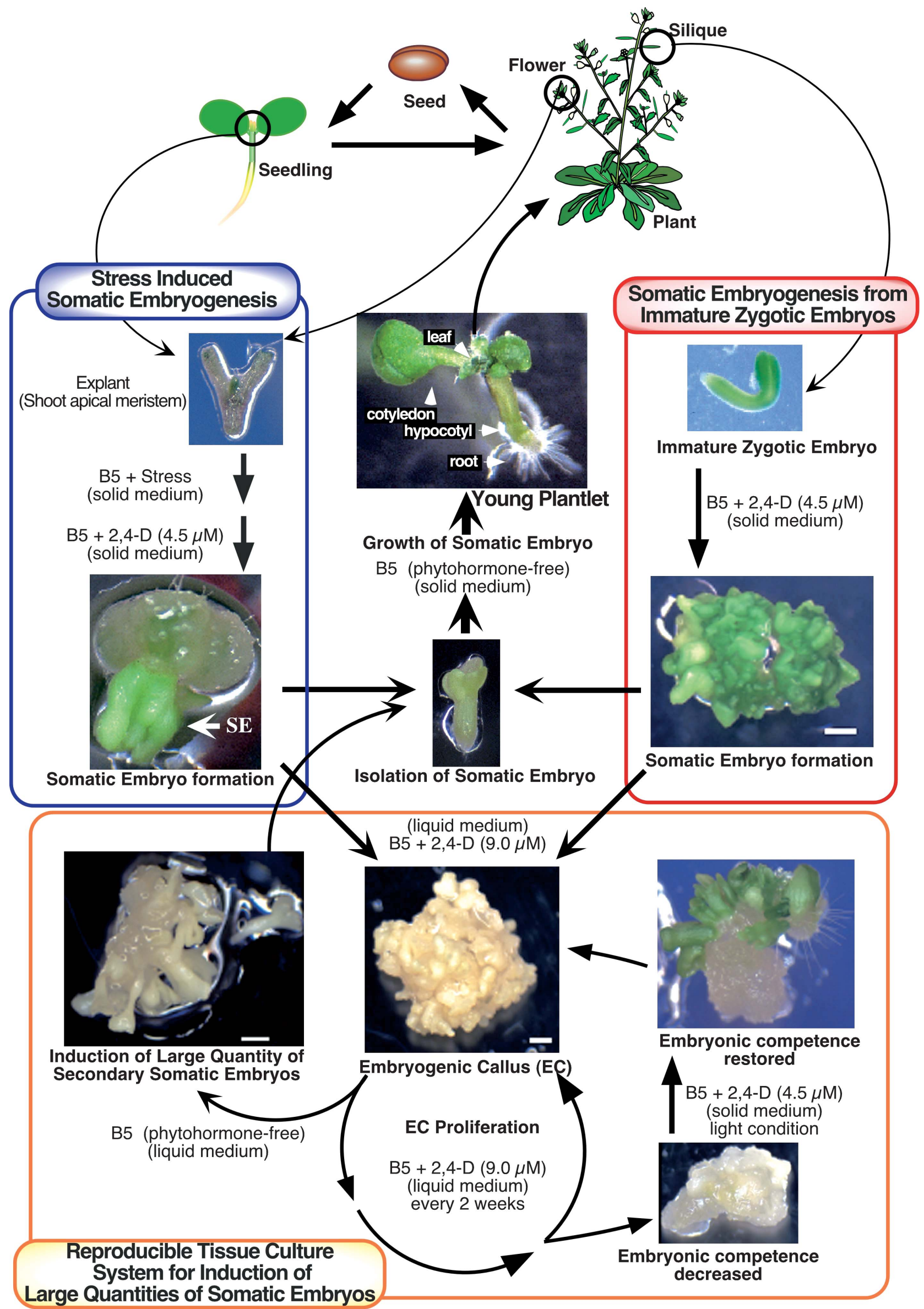


Table 1. Characteristics of somatic embryogenesis-related genes.

\begin{tabular}{llccc}
\hline \multirow{2}{*}{ Gene name } & \multicolumn{1}{c}{ Protein } & Target motif & \multicolumn{2}{c}{ Expression $^{\mathrm{b}}$} \\
\cline { 3 - 4 } & & & ZE & SE \\
\hline ABI3 & Transcription factor (B2, B3 domains) & G-box (ABRE), RY motif & + & + \\
FUS3 & Transcription factor (B3 domain) & RY motif & + & + \\
LEC1 & Transcription factor (HAP3) & CCAAT box & + & + \\
LEC2 & Transcription factor (B3 domain) & RY motif & + & + \\
SERK & Receptor kinase (Leucine-rich repeat) & GC[A/T $]_{8}$ GG & + & + \\
AGL15 & Transcription factor (MADS box) & nd & + & + \\
BBM & Transcription factor (AP2/ERF) & & + \\
\hline
\end{tabular}

${ }^{\text {a }}$ Target motif is the promoter cis-element that is bound to the protein complex including the encoded transcription factor.

${ }^{\mathrm{b}}$ Gene expression in ZE and SE.

- , The factor does not bind to promoter cis-element.

ZE, zygotic embryos; SE, somatic embryos; nd, not determined.

ECs and somatic embryos, can be easily obtained. This tissue culture system should be a powerful tool for molecular investigations.

\section{Stress-induced somatic embryogenesis in Arabidopsis}

Somatic embryos have also been induced from sources other than immature zygotic embryos. O'Neill and Mathias (1993) and Luo and Koop (1997) reported that somatic embryo-like structures could be induced from leaf protoplasts. In this method, protoplasts developed into somatic embryo-like structures, but they ceased development at the early globular stage.

On the other hand, tissue culture systems of stressinduced somatic embryogenesis have been established in carrot (Daucus carota). In these systems, somatic embryos can be induced by culturing shoot apical-tip explants on a phytohormone-free medium containing a stress chemical, such as $0.7 \mathrm{M}$ sucrose, $0.3 \mathrm{M} \mathrm{NaCl}$ or $0.6 \mathrm{mMCdCl}$, and then transferring the explants to a phytohormone-free medium without the stress chemical (Kamada et al. 1989, 1993; Kiyosue et al. 1989, 1990; Harada et al. 1990). Using a stress treatment similar to that of the carrot systems, Ikeda-Iwai et al. (2003) induced somatic embryos from excised shoot apical meristems of Arabidopsis seedlings and flower buds (Figure 1). Somatic embryos were induced by osmotic stress $(0.7 \mathrm{M}$ sorbitol, $0.7 \mathrm{M}$ mannitol, $0.7 \mathrm{M}$ sucrose or $0.3 \mathrm{M} \mathrm{NaCl})$, heavy metal ion stress $(0.6 \mathrm{mMCdCl})$, drought stress, and cold stress (Ikeda-Iwai et al. 2003; Umehara, unpublished data). This method required an additional 2,4-D treatment for somatic embryo formation. Somatic embryos were formed when shoot apical-tip explants were cultured on a phytohormonefree B5 solid medium containing a stress chemical and transferred to a solid B5 medium without the stress chemical but containing $4.5 \mu \mathrm{M}$ 2,4-D. The developmental stage of the explant material (i.e., days after sowing) also affected the frequency of somatic embryogenesis.

In the stress-induced somatic embryogenesis system, differentiation of Arabidopsis somatic cells (shoot apical meristem cells) and initiation of somatic embryogenesis can be controlled. This tissue culture system should be useful for analyzing the process of cell differentiation and the initiation of embryogenesis.

\section{Comparison of gene expression in somatic and zygotic embryos}

Some genes that are expressed during zygotic and somatic embryogenesis (Table 1) have been identified using two different techniques. In the first technique, genes or proteins involved in embryogenesis were isolated by comparing the patterns of gene and protein expression in embryonic, such as ECs and somatic embryos, and non-embryonic tissues, such as nonembryogenic cells and leaf mesophyll cells. In the other approach, genes involved in zygotic embryogenesis were identified using embryo-defective mutants. In this section, we describe the similarities of gene expression patterns between zygotic and somatic embryos.

\section{Genes and proteins isolated from cultured embryonic tissue}

Screening for somatic and zygotic embryogenesis-related genes by comparing embryonic and non-embryonic cultured cells started about 30 years ago, and the technique continues to be productive. Four of the bestknown embryogenesis-related factors (LEA, SERK, $A G L 15$ and $B B M$ ) identified by the method are discussed below.

\section{LEA (Late-Embryogenic Abundant) gene}

Since the late 1980 s, many researchers have attempted to isolate genes and proteins responsible for carrot somatic embryogenesis (e.g., Franz et al. 1989; Kiyosue et al. 1992, 1993). Most of the studies used a general differential screening method, and most of the genes identified in these experiments encoded lateembryogenesis abundant (LEA) proteins. The LEA proteins are proteins to be stored in seeds, and their 
genes are expressed in the late stage of zygotic embryogenesis. DC8, DC59, ECP31, ECP40 and ECP63 are typical $L E A$ genes isolated from carrot embryonic cultures. These genes are expressed in both embryonic cultures and immature seeds of carrot, but only in embryonic tissues and not in vegetative tissues. LEA gene expression has been found to be induced in somatic and zygotic embryos when they are treated with abscisic acid (ABA). The Arabidopsis homologs of carrot ECP31 and ECP63 (AtECP31 and AtECP63) were also expressed in somatic embryos and immature seeds but not in vegetative tissue (Yang et al. 1996; Yang et al. 1997; Ikeda-Iwai et al. 2002), and ABA also induced their expression in somatic embryos (Ikeda-Iwai et al. 2002). These results suggest that the embryo-specific $L E A$ genes that are expressed during zygotic embryogenesis are also expressed in somatic embryos and ECs, and ABA can induce the expression of the $L E A$ genes in both types of embryos.

\section{SERK (Somatic Embryogenesis Receptor Kinase)}

Somatic Embryogenesis Receptor Kinase (DcSERK) was isolated from carrot embryonic tissue culture (Schmidt et al. 1997). DCSERK has been found be expressed in somatic and zygotic embryos but in no other plant tissues at very early stages of somatic embryo development, i.e., from the single-cell stage to the globular stage (Schmidt et al. 1997). Genes homologous to DcSERK were isolated from Arabidopsis (AtSERKI), maize (ZmSERK1, ZmSERK2), Medicago truncatula (MtSERK1) and Hieracium (HpSERK), and their expressions were detected during somatic embryogenesis (Somleva et al. 2000; Baudino et al. 2001; Hecht et al. 2001; Shah et al. 2001; Nolan et al. 2003; Tucker et al. 2003; Thomas et al. 2004), as well as in developing ovules and early-stage embryos of Arabidopsis, Hieracium and maize. However, the expression of SERK homologs is not embryo-specific in Arabidopsis and in the other plants examined. SERK encodes a receptor-like kinase protein containing five leucine-rich repeats (Schmidt et al. 1997). When seedlings in which AtSERK1 was over-expressed were germinated in a medium containing 2,4-D, embryonic structures were formed at a rate three- to four-fold higher than that of wild-type embryogenesis (Hecht et al. 2001). These results suggest that SERK plays a role in an early stage of embryogenesis, although its actual function is still not understood.

\section{AGL15 (AGAMOUS-like 15)}

AGAMOUS-like 15 (AGL15) was isolated as a MADS box gene expressed in tissues of Arabidopsis and Brassica napus, which were derived by double fertilization (i.e., zygotic embryo, endosperm, and suspensor; Heck et al. 1995). Although AGL15 has been observed to be expressed also in vegetative tissues, its expression was especially strong in embryo-related tissues (Heck et al. 1995; Fernandez et al. 2000). The AGL15 protein has been found in embryonic tissues of both somatic and zygotic embryos in diverse plant species (Perry et al. 1999), and has been detected in dandelion during apomictic embryogenesis, in Brassica napus during microspore embryogenesis, and in alfalfa during somatic embryogenesis. Seedlings in which AGL15 was over-expressed formed somatic embryos at low frequency when germinated in a culture medium (Harding et al. 2003). AGL15 regulates the formation of somatic embryos via gibberellic acid (GA) synthesis. AGL15 protein directly regulates the expression of AtGA2ox6, which encodes the enzyme that converts bioactive GA into inactive GA. AGL15 that was ectopically expressed showed no somatic embryo induction activity in the background atga2ox6 (Wang et al. 2004). These findings suggest that the conversion of bioactive GA into inactive GA is enhanced by $A G L 15$ and that the quantity of bioactive GA is strongly related to somatic embryo formation in Arabidopsis.

\section{Baby Boom (BBM)}

The Baby Boom (BBM) gene, which was isolated from microspore embryo cultures of Brassica napus (Boutilier et al. 2002), encodes a transcriptional factor belonging to the $A P 2 / E R F$ family. $B B M$ expression was observed during zygotic and pollen-derived somatic embryogenesis. The ectopic expression of $B B M$ and Arabidopsis BBM (AtBBM) in transgenic plants induced the formation of somatic embryo-like structures on the edges of cotyledons and leaves, as well as additional pleiotropic phenotypes, including neoplastic growth, phytohormone-free plant regeneration from explants, and abnormal leaf and flower morphology. Therefore, $B B M$ is likely to promote cell proliferation and morphogenesis during embryogenesis (Boutilier et al. 2002).

\section{Genes identified using embryo-defective mutants} Four genes (LEC1, ABI3, LEC2 and FUS3) isolated from Arabidopsis embryo-defective mutants were found to be expressed mainly during zygotic embryogenesis. Recently, extensive analyses have been conducted on the expression of these embryo-related genes and their homologs during somatic embryogenesis.

\section{LEC1 (LEAFY COTYLEDON 1)}

LEAFY COTYLEDON 1 (LEC1) is a seed-specific transcriptional factor. Embryos of lecl mutants have an abnormal morphology, with trichomes on the cotyledons, and exhibit no desiccation tolerance and accumulate no seed storage proteins (Vicient et al. 2000; BrocardGifford et al. 2003). LECl gene expression was observed in developing seeds, and the ectopic expression of $L E C 1$ 
in transgenic plants induced the formation of somatic embryo-like structures (Lotan et al. 1998). This suggests that LEC1 has an important function in plant embryogenesis. The $L E C 1$ gene encodes a HAP3 subunit of the CCAAT-binding transcription factor (Lotan et al. 1998; Lee et al. 2003). Expression of LEC1 and LEC1homologs was observed during somatic embryogenesis in Arabidopsis, maize and carrot in the same pattern (Ikeda-Iwai et al. 2002; Zhang et al. 2002; Yazawa et al. 2003), further indicating that LECl has a common and important role in both zygotic and somatic embryogenesis.

\section{FUS3 (FUSCA3) and LEC2 (LEAFY COTYLEDON2)}

Embryos of the fusca 3 mutant (fus3) were shown to have increased accumulations of anthocyanin and decreased accumulations of seed storage proteins from wild-type embryos (Luerßen et al. 1998). Expression of the FUS3 gene was observed in developing embryos from a very early stage. The introduction of the AtML1: FUS3 gene into Arabidopsis induced the expression of FUS3 in the L1 layer of the shoot apical meristem (SAM), resulting in the production of cotyledon-like organs in the transgenic Arabidopsis SAM (Gazzarrini et al. 2004).

Embryos of the leafy cotyledon2 mutant (lec2) produced trichomes on the cotyledons and displayed abnormal suspensor morphology. The expression of $L E C 2$ is silique-specific. The ectopic expression of the $L E C 2$ gene induced the formation of somatic embryolike structures and other organ-like structures (such as leaf-like, cotyledon-like and shoot), and often conferred embryonic characteristics to seedlings (Stone et al. 2001). The FUS3 and LEC 2 genes encode a $\mathrm{B} 3$ domaincontaining protein, and the domain is conserved in $A B I 3-$ type transcription factors. The FUS3 and LEC2 proteins bind directly to the RY motif and regulate the expression of some embryonic genes (Kroj et al. 2003; Mönke et al. 2004).

Although the expression of FUS3 occurs in somatic embryos of Arabidopsis (Ikeda-Iwai et al. 2002; IkedaIwai et al. 2003), the functions of FUS3 during somatic embryogenesis are not fully understood, and the expression of $L E C 2$ during somatic embryogenesis remains to be examined.

\section{ABI3 (ABA INSENSITIVE 3)/ VP1 (VIVIPAROUS1)} Arabidopsis ABA-insensitive 3 (abi3) and maize viviparous $1(v p l)$ are seed-specific, ABA-insensitive mutants. Seeds of these mutants undergo viviparous germination, and exhibit no seed dormancy, acquire no desiccation tolerance and accumulate little seed storage proteins. The low expression levels of some $L E A$ genes in these mutants suggest that $A B I 3 / V P 1$ may be an important factor in controlling the expression of the $L E A$ genes (Parcy et al. 1994).
Expression of $A B I 3 / V P 1$ has been observed mainly in embryos. $A B I 3 / V P 1$ expression during zygotic embryogenesis begins at a very early stage and is detected continuously until the late stage of embryogenesis. Many $A B I 3 / V P 1$ homologs have been isolated from a variety of plant species. Ikeda-Iwai et al. (2002, 2003) and Shiota et al. (1998) reported that $A B I 3$ and $C-A B I 3$ (carrot homolog of $A B I 3$ ) was expressed during both zygotic and somatic embryogenesis in Arabidopsis and carrot. ABI3/VP1 regulates ABAinduced gene expression during both zygotic and somatic embryogenesis.

\section{Molecular mechanisms of ABA signaling in embryogenesis}

As described above, expression of some embryogenesisrelated genes has been observed during both zygotic and somatic embryogenesis. In this chapter, the relationship between the expression of these genes and the ABA signaling pathway is explored.

\section{$A B A$ signal transduction during zygotic embryogenesis}

In the late stage of zygotic embryogenesis, endogenous ABA level in embryo increases, followed by the accumulation of seed storage proteins. These embryos acquire desiccation tolerance, show decreases in water, and become dormant seeds. The LEAs are critical proteins for zygotic embryos to acquire the desiccation tolerance and seed dormancy. Expression of the LEA genes during zygotic embryogenesis is regulated by $\mathrm{ABA}$, and $A B I 3 / V P 1$ is a major transcriptional factor for regulating the expression of the LEA genes in zygotic embryos (Giraudat et al. 1992; Suzuki et al. 2003). $A B I 3 / V P 1$ contains three conserved domains (B1, B2, and B3), of which B2 and B3 may be involved in seedspecific gene expression. Analyses of the mechanisms regulating the expression of seed-specific ABA-inducible genes (Em and Osem) suggest that the B2 domain of $A B I 3 / V P 1$ regulates the expression of ABA-inducible genes via the cis-regulatory $\mathrm{ABA}$ responsive element (ABRE) which resembles the G-box element (Marcotte et al. 1989; Hattori et al. 1995). In this regulatory scheme, $A B I 3 / V P 1$ does not bind to ABRE directly, but may form a complex with bZIP proteins, which then binds to ABRE (Figure 2; Gultinan et al. 1990; Nakagawa et al. 1996; Nantel and Quatrano 1996; Lopez-Molina et al. 2002; Lara et al. 2003).

\section{Seed dormancy in somatic embryos}

Unlike zygotic embryos, somatic embryos do not become dormant. Somatic embryos do not cease to develop at the late stage of embryogenesis, but germinate immediately. Although the expression of $A B I 3$ and the 

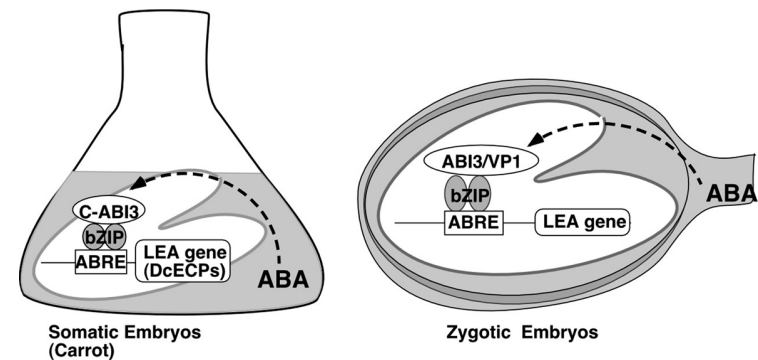

Figure 2. The regulation of $L E A$ gene expression by $A B A$ and $\mathrm{ABI} 3 / \mathrm{C}-\mathrm{ABI} 3$. The regulatory system of $L E A$ gene expression may be similar in zygotic and somatic embryogenesis. In this regulatory system, ABI3/VP1 may form a complex with bZIP proteins, and binds to ABRE.

carrot homolog $C-A B I 3$ have been detected in somatic embryos and embryonic tissues of Arabidopsis and carrot (Shiota et al. 1998, Ikeda-Iwai et al. 2002, 2003), the expression level of the LEA genes was found to be very low in somatic embryos (Kamada 1996; Ikeda-Iwai et al. 2002). This is likely attributable to the very low level of endogenous ABA in somatic embryos (Kamada and Harada 1981). When somatic embryos were treated with the optimum concentration of ABA, expression of the LEA genes increased immediately (Kamada 1996; Ikeda-Iwai et al. 2002).

ABA-treated somatic embryos acquired desiccation tolerance (Shiota et al. 1999). When ABA-treated somatic embryos were rapidly desiccated by silica gel, the embryos survived for more than 169 weeks at $-25^{\circ} \mathrm{C}$ (Shiota et al. 1999). After desiccation, the water content of the somatic embryos decreased to $5 \%$, and the embryos ceased to develop, like dormant seeds (Shiota et al. 1999). These results indicate that somatic embryos are physiologically similar to zygotic embryos.

\section{ABA signal transduction in somatic embryogenesis}

ABA regulates the expression of the $L E A$ genes in both zygotic and somatic embryos, and the expression of $A B I 3 / C-A B I 3$ has been detected in zygotic embryos (Giraudat et al. 1992; Suzuki et al. 2003) and in somatic embryos of Arabidopsis and carrot (Shiota et al. 1998, Ikeda-Iwai et al. 2002, 2003). Thus, the mechanisms for regulating the expression of the $L E A$ genes are likely to be the same in somatic and zygotic embryos.

Ko et al. $(2001 \mathrm{a}, \mathrm{b})$ showed that ABRE promoter ciselements are also involved in the expression regulation of ECP31 and ECP63 (LEA genes) by $C-A B I 3$ and ABA during carrot somatic embryogenesis, but $C-A B I 3$ does not bind directly to ABRE (Ko and Shiota, unpublished data). Ko and Kamada (2002) showed that two bZIP proteins (clone 22 and DcBZ43) isolated from a carrot EC cDNA library bind to the ECP31 promoter ciselement. It is possible that these bZIP proteins and C$\mathrm{ABI} 3$ form a complex and that the complex binds to
ABRE on the ECP31 promoter, and induce the expression of ECP31 during somatic embryogenesis in carrot. The regulatory system of $L E A$ gene expression may be similar in zygotic and somatic embryogenesis (Figure 2).

\section{Conclusions}

The majority of the mechanisms that regulate plant embryogenesis still remain to be clarified. In the higher plants, some genes and factors related to important mechanisms of embryogenesis are plant-specific (e.g., various phytohormones and $\mathrm{B} 3$ domain-containing genes (ABI3, FUS3 and LEC2)). No knowledge about these plant-specific factors can be gained from experimental data on animal embryos (e.g., mammalian embryogenesis). On the other hand, the availability of model systems of plant somatic embryogenesis has created effective tools for examining the details of plant embryogenesis. Actually, studies that used carrot somatic embryogenesis systems revealed the molecular mechanisms in charge of controlling the expression of the $C-A B I 3$ gene during somatic embryogenesis (Ikeda unpublished data). We expect that new findings, such as discovery and identification of new factors that control the expression of embryogenesis-related genes and embryogenesis-specific phytohormone response, be made in near future, as a result of thorough investigation of embryo-defective mutants and use of somatic embryogenesis. The molecular mechanisms of plant embryogenesis might be clarified by experiments using somatic and zygotic embryogenesis.

\section{Acknowledgements}

This research was supported in part by a Grant-in-Aid from the "Research for the Future" Program from the Japan Society for the Promotion of Science (JSPS-RFTF00L01601).

\section{References}

Baudino S, Hansen S, Brettschneider R, Hecht VEG, Dresselhaus T, Lorz H, Dumas C, Rogowsky PM (2001) Molecular characterization of two novel maize LRR receptor-like kinases, which belong to the SERK gene family. Planta 213: 1-10

Boutilier K, Offringa R, Sharma VK, Kieft H, Ouellet T, Zhang L, Hattori J, Liu C-M, van Lammeren AAM, Miki BLA, Custers JBM, van Lookeren Campage MM (2002) Ectopic expression of BABY BOOM triggers a conversion from vegetative to embryonic growth. Plant Cell 14: 1737-1749

Brocard-Gifford IM, Lynch TJ, Finkelstein RR (2003) Regulatory networks in seeds integrating developmental, abscisic acid, sugar, and light signaling. Plant Physiol 131: 78-92

Fernandez DE, Heck GR, Perry SE, Patterson SE, Bleecker AB, Fang S-C (2000) The embryo MADS domain factor AGL15 acts post-embryonically: inhibition of perianth senescence and abscission via constitutive expression. Plant Cell 12: 183-197 
Franz G, Hatzopoulos P, Jones TJ, Krauss M, Sung ZR (1989) Molecular and genetic analysis of an embryonic gene, DC8, from Daucus carota L. Mol Gen Genet 218: 143-151

Gazzarrini S, Tsuchiya Y, Lumba S, Okamoto M, McCourt P (2004) The transcription factor FUSCA3 controls developmental timing in Arabidopsis through the hormones gibberellin and abscisic acid. Dev Cell 7: 373-385

Giraudat J, Hauge BM, Valon C, Smalle J, Parcy F, Goodman HM (1992) Isolation of the Arabidopsis ABI3 gene by positional cloning. Plant Cell 4: 1251-1261

Guiltinan MJ, Marcotte WR, Quatrano RS (1990) A plant leucine zipper protein that recognizes an abscisic acid response element. Science 12: 267-271

Harada H, Kiyosue T, Kamada H, Kobayashi T. (1990) Stressinduced carrot somatic embryogenesis and its application to synthetic seed. In: Sangwan RS, Sangwan-Norreel BS (eds) The Impact of Biotechnology in Agriculture. Kluwer Academic Publishers, pp 129-157

Harding EW, Tang W, Nichols KW, Fernandez DE, Perry SE (2003) Expression and maintenance of embryogenic potential is enhanced through constitutive expression of AGAMOUS-like 15. Plant Physiol 133: 653-663

Hattori T, Terada T, Hamasuna S (1995) Regulation of the Osem gene by abscisic acid and the transcriptional activator VP1: analysis of cis-acting promoter elements required for regulation by abscisic acid and VP1. Plant J 7: 913-925

Hecht V, Vielle-Calzada J-P, Hartog MV, Schmidt EDL, Boutilier K, Grossniklaus U, de Vries SC (2001) The Arabidopsis SOMATIC EMBRYOGENESIS RECEPTOR KINASE1 gene is expressed in developing ovules and embryos and enhances embryogenic competence in culture. Plant Physiol 127: 803-816

Heck GR, Perry SE, Nichols KW, Fernandez DE (1995) AGL15, a MADS domain protein expressed in developing embryos. Plant Cell 7: 1271-1282

Ikeda-Iwai M, Satoh S, Kamada H (2002) Establishment of a reproducible tissue culture system for the induction of Arabidopsis somatic embryos. J Exp Bot 53: 1575-1580

Ikeda-Iwai M, Umehara M, Satoh S, Kamada H (2003) Stressinduced somatic embryogenesis in vegetative tissues of Arabidopsis thaliana. Plant J 34: 107-114

Kamada H, Harada H (1981) Changes in endogenous level and effects of abscisic acid during somatic embryogenesis of Daucus carota L. Plant Cell Physiol 22: 1423-1429

Kamada H, Kobayashi T, Kiyosue T, Harada H (1989) Stress induced somatic embryogenesis in carrot and its application to synthetic seed production. In Vitro Cell Develop Biol 25: 1163-1166

Kamada H, Ishikawa K, Saga H, Harada H (1993) Induction of somatic embryogenesis in carrot by osmotic stress. Plant Tissue Culture Letters 10: 38-44

Kamada H (1996) Physiological and molecular biological studies on somatic embryogenesis. Chem Reg Plants (Shokubutuno Kagaku Chousetu) 31: 1-11 (in Japanese)

Kiyosue T, Kamada H, Harada H (1989) Induction of somatic embryogenesis by salt stress in carrot. Plant Tissue Culture Letters 6: 162-164

Kiyosue T, Takano K, Kamada H, Harada H (1990) Induction of somatic embryogenesis in carrot by heavy metal ions. Can $J$ Bot 68: 2301-2303

Kiyosue T, Yamaguchi-Shinozaki K, Shinozaki K, Higashi K, Satoh S, Kamada H, Harada H (1992) Isolation and characterization of a cDNA that encodes ECP31, an embryogenic-cell protein from carrot. Plant Mol Biol 19: 239-249

Kiyosue T, Yamaguchi-Shinozaki K, Shinozaki K, Kamada H, Harada H (1993) cDNA cloning of ECP40, an embryogenic-cell protein in carrot, and its expression during somatic and zygotic embryogenesis. Plant Mol Biol 21: 1053-1068

Ko S, Thitamadee S, Yang H, Eun C-H, Sage-ono K, Higashi K, Satoh S, Kamada H (2001a) Comparison and characterization of cis-regulatory region in some embryo-specific and ABAresponsive carrot genes, DcECPs. Plant Biotech 18: 45-54

Ko S, Eun C-H, Satoh S, Kamada H (2001b) Analysis of cisregulatory elements in carrot embryo-specific and ABAresponsive gene, DcECP31. Plant Biotech 18: 55-60

Ko S, Kamada H (2002) Isolation of carrot basic leucine zipper transcription factor using yeast one-hybrid screening. Plant Mol Biol Rep 20: 1-8

Kroj T, Savino G, Valon C, Giraudat J, Parcy F (2003) Regulation of storage protein gene expression in Arabidopsis. Development 130: 6065-6073

Lara P, Onate-Sanchez L, Abraham Z, Ferrandiz C, Diaz I, Carbonero P, Vicente-Carbajosa J (2003) Synergistic activation of seed storage protein gene expression in Arabidopsis by ABI3 and two bZIPs related to OPAQUE2. J Biol Chem 278: 21003-21011

Lee H, Fisher RL, Goldberg RB, Harada JJ (2003) Arabidopsis LEAFY COTYLEDON1 represents a functionally specialized subunit of the CCAAT binding transcription factor. Proc Natl Acad Sci USA 18: 2152-2156

Lopez-Molina L, Mongrand S, McLachlin DT, Chait BT, Chua N$\mathrm{H}$ (2002) ABI5 acts downstream of ABI3 to execute an ABAdependent growth arrest during germination. Plant $J 32$ : 317-328

Lotan T, Ohto M, Yee KM, West MAL, Lo R, Kwong RW, Yamagishi K, Fisher RL, Goldberg RB, Harada JJ (1998) Arabidopsis LEAFY COTYLEDON1 is sufficient to induce embryo development in vegetative cells. Cell 93: 1195-1205

Luerßen H, Kirik V, Herrmann P, Misera S (1998) FUSCA3 encodes a protein with a conserved VP1/ABI3-like B3 domain which is of functional importance for the regulation of seed maturation in Arabidopsis thaliana. Plant J 15: 755-764

Luo Y, Koop HU (1997) Somatic embryogenesis in cultured immature zygotic embryos and leaf protoplasts of Arabidopsis thaliana ecotypes. Planta 202: 387-396

Marcotte WR, Russell SH, Quatrano RS (1989) Abscisic acidresponsive sequences from the Em gene of wheat. Plant Cell 1: 969-976

Mönke G, Altschmied L, Tewes A, Reidt W, Mock H-P, Bäumlein H, Conrad U (2004) Seed-specific transcription factors ABI3 and FUS3: molecular interaction with DNA. Planta 219: 158-166

Nakagawa H, Ohmiya K, Hattori T (1996) A rice bZIP protein, designated OSBZ8, is rapidly induced by abscisic acid. Plant $J$ 9: 217-227

Nantel A, Quatrano R (1996) Characterization of three rice basic/leucine zipper factors, including two inhibitors of EmBP-1 DNA binding activity. J Biol Chem 271: 31296-31305

Nolan KE, Irwanto RR, Rose RJ (2003) Auxin up-regulates MtSERK1 expression in both Medicago truncatula root-forming and embryogenic cultures. Plant Physiol 133: 218-230

O'Neill CM, Mathias RJ (1993) Regeneration of plants from protoplasts of Arabidopsis thaliana L. cv. Columbia (C24), via 
direct embryogenesis. J Exp Bot 44: 1579-1585

Parcy F, Valon C, Raynal M, Gaubier-Comella P, Delseny M, Giraudat J (1994) Regulation of gene expression programs during Arabidopsis seed development: Roles of the ABI3 locus and of endogenous abscisic acid. Plant Cell 6: 1567-1582

Perry SE, Lehti MD, Fernandez DE (1999) The MADS-domain protein AGAMOUS-like 15 accumulates in embryonic tissues with diverse origins. Plant Physiol 120: 121-129

Pillon E, Terzi M, Baldan B, Mariani P, Schiavo FL (1996) A protocol for obtaining embryogenic cell lines from Arabidopsis. Plant J 9: 573-577

Reinert J (1958) Untersuchungen über die Morphogenese an Gewebekulturen. Ber Dtsch Bot Ges 71: 15

Sangwan RS, Bourgeois Y, Dubois F, Sangwan-Norreel BS (1992) In vitro regeneration of Arabidopsis thaliana from cultured zygotic embryos and analysis of regenerants. J Plant Physiol 140: 588-595

Schmidt EDL, Guzzo F, Toonen MA, de Vries SC (1997) A leucine-rich repeat containing receptor-like kinase marks somatic plant cells competent to form embryos. Development 124: 2049-2062

Shah K, Gadella TWJ, van Erp H, Hecht V, de Vries SC (2001) Subcellular localization and oligomerization of the Arabidopsis thaliana somatic embryogenesis receptor kinase 1 protein. $J$ Mol Biol 309: 641-655

Shiota H, Satoh R, Watabe K, Harada H, Kamada H (1998) C$A B I 3$, the carrot homologue of the Arabidopsis ABI3, is expressed during both zygotic and somatic embryogenesis and functions in the regulation of embryo-specific ABA-inducible genes. Plant Cell Physiol 39: 1184-1193

Shiota H, Tachikawa K, Watabe K, Kamada H (1999) Successful long-term preservation of abscisic-acid-treated and desiccated carrot somatic embryos. Plant Cell Rep 18: 749-753

Somleva MN, Schmidt EDL, de Vries SC (2000) Embryogenic cells in Dactylis glomerata L. (Poaceae) explants identified by cell tracking and by SERK expression. Plant Cell Rep 19: $718-726$

Steward FC, Mapes MO, Mears K (1958) Growth and organized development of cultured cells. II. Organization in cultures grown from freely suspended cells. Am J Bot 45: 705-708

Stone SL, Kwong LW, Yee KM, Pelletier J, Lepiniec L, Fischer RL, Goldberg RB, Harada JJ (2001) LEAFY COTYLEDON2 encodes a B3 domain transcription factor that induces embryo development. Proc Natl Acad Sci USA 98: 11806-11811
Suzuki M, Kao C-Y, Cocciolone S, McCarty DR (2001) Maize VP1 complements Arabidopsis abi3 and confers a novel ABA/auxin interaction in roots. Plant J 28: 409-418

Suzuki M, Ketterling MG, Li Q-B, McCarty DR (2003) Viviparous1 alters global gene expression patterns through regulation of abscisic acid signaling. Plant Physiol 132: $1664-1677$

Thomas C, Meyer D, Himber C, Steinmetz A (2004) Spatial expression of a sunflower SERK gene during induction of somatic embryogenesis and shoot organogenesis. Plant Physiol Biochem 42: 35-42

Tucker MR, Araujo ACG, Paech NA, Hecht V, Schmidt EDL, Bossell JB, de Vries SC, Koltunow AMG (2003) Sexual and apomictic reproduction in Hieracium subgenus Pilosella are closely interrelated developmental pathways. Plant Cell 15: $1524-1537$

Vicient CM, Bies-Etheve N, Delseny M (2000) Changes in gene expression in the leafy cotyledon1 (lec1) and fusca3 (fus3) mutants of Arabidopsis thaliana L. J Exp Bot 51: 995-1003

Wang H, Caruso LV, Downie AB, Perry SE (2004) The embryo MADS domain protein AGAMOUS-like 15 directly regulates expression of a gene encoding an enzyme involved in gibberellin metabolism. Plant Cell 16: 1206-1219

Wu Y, Haberland G, Zhou C, Koop HU (1992) Somatic embryogenesis, formation of morphogenetic callus and normal development in zygotic embryos of Arabidopsis thaliana in vitro. Protoplasma 169: 89-96

Yang H, Saitou T, Komeda Y, Harada H, Kamada H (1996) Late embryogenesis abundant protein in Arabidopsis thaliana homologous to carrot ECP31. Physiol Plant 98: 661-666

Yang H, Saitou T, Komeda Y, Harada H, Kamada H (1997) Arabidopsis thaliana ECP63 encoding a LEA protein is located in chromosome 4. Gene 184: 83-88

Yazawa K, Takahata K, Kamada H (2003) Isolation of the gene that encodes carrot leafy cotyledon 1 and expression analysis during somatic and zygotic embryogenesis. Plant Physiol Biochem 42: $215-223$

Zhang S, Wong L, Meng L, Lemaux PG (2002) Similarity of expression patterns of knotted 1 and $Z m L E C l$ during somatic and zygotic embryogenesis in maize (Zea mays L.). Planta 215: 191-194

Zimmerman JL (1993) Somatic embryogenesis: a model for early development in higher plants. Plant Cell 5: 1411-1423 